\title{
HEAVY METALS IN WATER, SEDIMENT AND THREE FISH SPECIES OF DHALESHWARI RIVER, SAVAR
}

\author{
Liton Chandra Mohanta ${ }^{1}$, Md. Nazmul Hasan Niloy, Gawsia Wahidunnessa \\ Chowdhury*, Dipa Islam ${ }^{1}$ and Evena Parvin Lipy ${ }^{1}$ \\ Department of Zoology, University of Dhaka, Dhaka-1000, Bangladesh
}

\begin{abstract}
The study was conducted to assess the pollution of five heavy metals, namely arsenic (As), lead $(\mathrm{Pb})$, cadmium $(\mathrm{Cd})$, chromium $(\mathrm{Cr})$ and copper $(\mathrm{Cu})$. Their concentrations in water and sediments as well as in three fish species such as Labeo rohita (herbivorous), Wallago attu (carnivorous) and Heteropneustes fossilis (omnivorous) were recorded. During wet and dry seasons $\mathrm{As}, \mathrm{Pb}, \mathrm{Cd}, \mathrm{Cr}$, $\mathrm{Cu}$ concentrations in river water ranged from the 'below detection level (BDL)'$0.0019,0.3702-0.4163,0.0285-0.0294,1.204-1.36,0.0315-0.0807 \mathrm{ppm}$ and $0.0016-0.0180,0.1305-0.1889,0.0297-0.0309$, BDL, $0.0381-0.0543$ ppm, respectively. There was no significant seasonal variation in As and $\mathrm{Cu}$ conc. in river water but $\mathrm{Cr}$ and $\mathrm{Pb}$ conc. were significantly higher during the wet season and Cd conc. was significantly higher during dry season. During the wet and dry seasons $\mathrm{As}, \mathrm{Pb}, \mathrm{Cd}, \mathrm{Cr}, \mathrm{Cu}$ conc. in river sediments ranged from $3.67-7.13$, 21.58 - 64.96, 1.36 - 1.72, 1126.66 - 1199.46, $45.91-115.57 \mathrm{ppm}$ and $5.10-$ 8.88, 19.27 - 30.75, 1.39 - 1.48, 99.67 - 446.72, 68.98 - 442.78 ppm, respectively. There were no significant seasonal variations in $\mathrm{As}, \mathrm{Pb}, \mathrm{Cd}$ and $\mathrm{Cu}$ concentrations of river sediment but $\mathrm{Cr}$ concentration was significantly higher during the wet season. Among muscle, gill and gut tissues of three selected fish species, $\mathrm{Pb}$ showed the highest level of accumulation in gill tissues while As showed the lowest level of accumulation in muscle tissues in all three species. $\mathrm{Pb}, \mathrm{Cd}$ and $\mathrm{Cr}$ concentrations in the river water were above WHO Guideline values while As and $\mathrm{Cu}$ concentrations were below WHO Guideline values. $\mathrm{As}, \mathrm{Pb}, \mathrm{Cd}, \mathrm{Cr}$ and $\mathrm{Cu}$ concentrations in the river sediment were above the environmental protection agency's threshold effect level. In all the three studied fish species, As conc. was below FAO guideline value. $\mathrm{Pb}, \mathrm{Cd}$ and $\mathrm{Cr}$ conc. were higher than $\mathrm{FAO}$ guideline value in all three fish species and $\mathrm{Cu}$ conc. was above $\mathrm{FAO}$ guideline value in one species (H. fossilis). At least three heavy metal concentrations were above FAO guideline value in all three fish species. Therefore, all three fish species were not safe for human consumption.
\end{abstract}

Key words: Heavy metals, conc. of heavy metal, seasonal variation, tannery

\section{INTRODUCTION}

Heavy metal pollution is considered as a major environmental crisis because of its non-degradable nature, metal ions continue to exist in the atmosphere and also in aquatic organisms (Ayangbenro and Babalola 2017). Metal pollutants enter into river water through anthropogenic sources such as long-term disposal

*Author for correspondence: <gawsia@gmail.com/gawsia@du.ac.bd>. ${ }^{1}$ Biomedical and Toxicological Research Institute (BTRI), Institute of Food Science and Technology (IFST), Bangladesh Council of Scientific and Industrial Research (BCSIR), Dhaka, Bangladesh.

@2019 Zoological Society of Bangladesh DOI: https://doi.org/10.3329/bjz.v47i2.44337 
of untreated and partially treated industrial effluents that contains toxic heavy metals and use of fertilizers and pesticides that contain metals in agricultural lands (Martin 2000, Macklin et al. 2006, Reza and Singh 2010). Metals accumulate in sediment at a considerable amount and finally enter into the food chain through water and plants (Bhuyan and Islam 2017). Fishes are the most important aquatic biota and are susceptible to heavy metals pollution (Akan et al. 2012). So, the consumption of polluted fish with substantial metals can bring about perilous impacts on humans (Mai et al. 2006).

The grouping of metals ends up poisonous to the organisms when the level surpasses the acceptable level (Mansour and Sidky 2002). But this acceptable limit varies among different metals and also among different species (Mansour and Sidky 2002). Thus, the determination of heavy metal levels in water, sediment and fish sample is considered as the useful and key test in environmental pollution assessment.

During the most recent decade, fast urbanization and industrialization have influenced some serious problems in environment and metals contamination is one of the arising concerns worldwide particularly in developing countries, for example, Bangladesh (Bhuiyan and Islam 2017). According to Satter and Islam (2005), about $10 \%$ of industries released treated effluents and the remainder of the enterprises released the untreated effluent in the streams or water bodies. The Buriganga river has been reported as one of the seriously polluted by the untreated industrial effluents that directly discharged into the river from the Hazaribagh tanneries besides other man made pollutions (Alam 2003). Understanding the dangerous effect of tannery wastes on humans and environment, the Government of Bangladesh has been executing an initiative entitled 'Hazaribagh Tannery Relocation Project (HTRP)' to move Hazaribagh Tannery Complex to a new site in Savar. Under this project, a dedicated industrial park in Savar has been initiated and installation of the Central Effluent Treatment Plant (CETP) is part of it. However, the installation of the CETP has not yet been completed. In absence of a fully functional CETP, the tanneries are now polluting the Dhaleshwari River in Savar by dumping untreated effluents directly to the river. Therefore, the objectives of this study were to analyze heavy metal pollution in water and sediment during wet and dry seasons and to assess the accumulation of 5 heavy metals in muscle, gill and gut tissues of three fish species of the Dhaleshwari River.

\section{MATERIAL AND METHODS}

Water, sediment and fish samples were collected from the Dhaleshwari River at Tannery Industrial Estate in Savar, Dhaka (2346 $\left.52.68 " \mathrm{~N}, 90^{\circ} 14^{\prime} 22.58^{\prime \prime E}\right)$. Water and sediment samples were collected from five spots: spot 1, spot 2, spot 
3, spot 4 and spot 5 (Fig. 1). Each spot was half a kilometer apart from one another.

The study was conducted during July, 2018 - June, 2019. Sampling was done six times during the study period to cover both wet and dry seasons. Water and sediment samples were collected during both wet and dry seasons but fish samples were collected only during the wet season

Samples collection, preservation and analysis: Fish species were selected by their feeding habit and availability. Labeo rohita, Wallago attu, and Heteropneustes fossilis as the representative of the three feeding groups such as herbivorous, carnivorous and omnivorous (IUCN Bangladesh 2015) were studied.

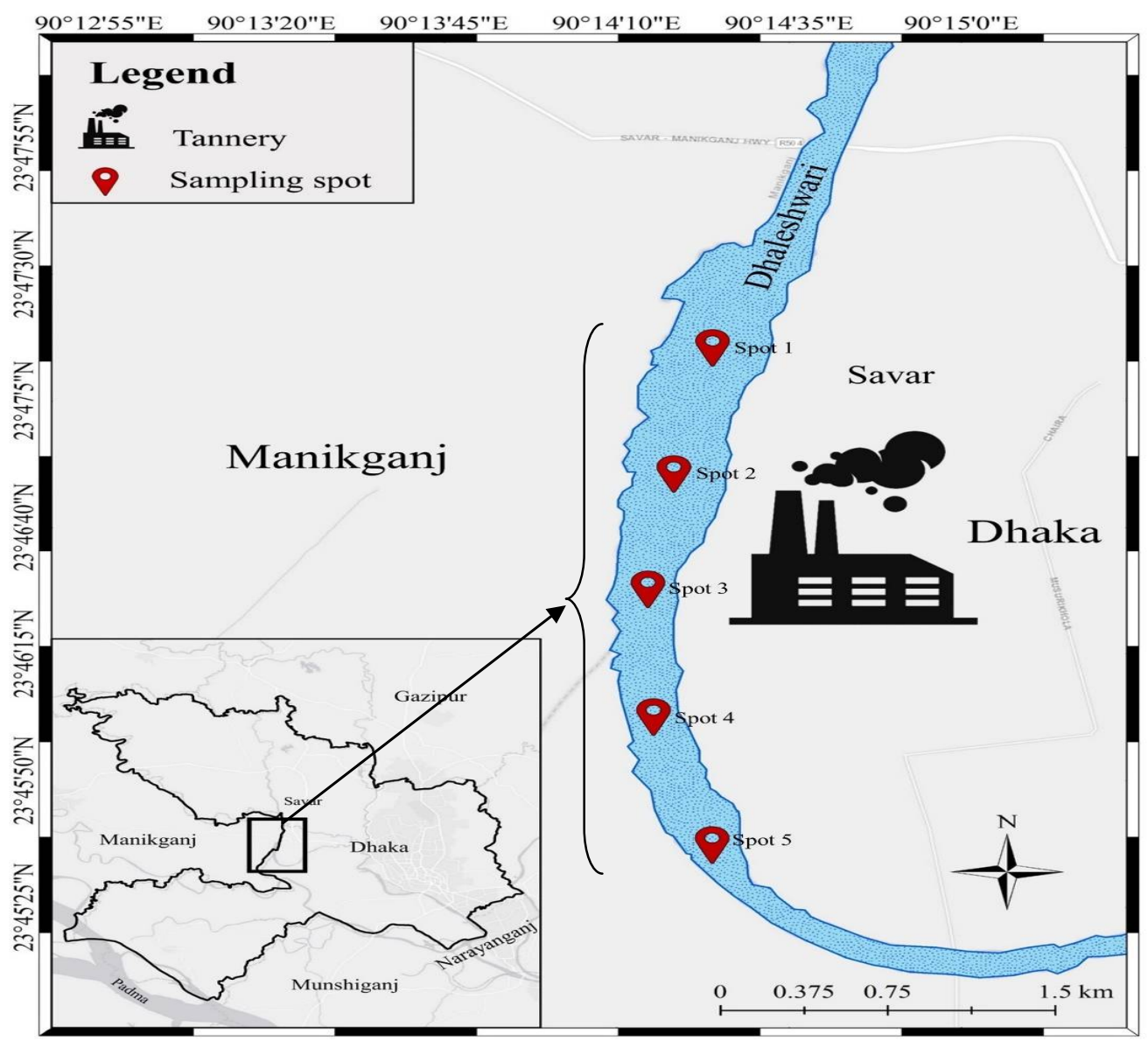

Fig. 1. Location of the five sampling spots in the Dhaleshwari river. 
Three samples of water and sediments were collected from each spot following EPA (1997) guidelines. Three samples of each of the three fish species were collected from a fish retailer of Dhar Fish Market, Rajfulbaria, Savar $\left(23^{\circ} 48^{\prime} 35.84 " \mathrm{~N}, 90^{\circ} 14^{\prime} 59.71^{\prime \prime} \mathrm{E}\right)$ who sells freshly caught fish from Tannery Estate area of Dhaleshwari River. Same sized fish samples were collected to avoid sampling error. Collected fish samples were kept in an ice box and transported to the laboratory the same day for identification and dissection then preserved at $-20^{\circ} \mathrm{C}$ in the refrigerator at the Biomedical and Toxicological Research Institute (BTRI), Institute of Food Science and Technology (IFST), Bangladesh Council of Scientific and Industrial Research (BCSIR), Dhaka, Bangladesh.

Digestion of samples: Water samples were not required to digest and stored in $100 \mathrm{ml}$ volumetric flask after filtration. Collected sediment and fish samples were sun-dried and homogenized using mortar and pestle. Dried samples were prepared and analyzed according to AOAC guidelines (AOAC 2002). $1 \mathrm{~g}$ dry sample was weighed using an electronic balance and placed in a $100 \mathrm{ml}$ beaker to which $10 \mathrm{ml}$ of aqua regia $\left(35 \% \mathrm{HCl}\right.$ and $70 \%$ high purity $\mathrm{HNO}_{3}$, in $3: 1$ ratio) was added. The mixture was then digested at $70^{\circ} \mathrm{C}$ on a hotplate until the solution became transparent. The resulting solution was filtered through filter paper, poured into a $100 \mathrm{ml}$ volumetric flask and diluted using deionized water to make a total volume of $100 \mathrm{ml}$.

Heavy metal analysis: Assessment of five heavy metal contents of the samples was performed with Atomic Absorption Spectrophotometer (Model: Shimadzu AA-7000) utilizing acetylene gas as fuel and air as an oxidizer. Digested samples were aspirated into the fuel-rich air acetylene flame and the metal concentrations were determined from the calibration curves obtained from standard solutions. Each determination was based on the average values of three replicate samples. Prior to Atomic Absorption Spectrophotometer (AAS) analysis, digested samples were homogenized using a sonicator. The absorption wavelengths and below detection level (BDL) for the heavy metals were $193.7 \mathrm{~nm}$ and $0.001 \mathrm{ppm}$ for As, $217.0 \mathrm{~nm}$ and $0.1 \mathrm{ppm}$ for $\mathrm{Pb}, 228.8 \mathrm{~nm}$ and $0.012 \mathrm{ppm}$ for $\mathrm{Cd}, 324.7 \mathrm{~nm}$ and $0.04 \mathrm{ppm}$ for $\mathrm{Cu}$ and $232.0 \mathrm{~nm}$ and $0.08 \mathrm{ppm}$ for $\mathrm{Cr}$. World Health Organization's guideline value (WHO 2006) for water $\mathrm{As}, \mathrm{Pb}, \mathrm{Cd}$, $\mathrm{Cr}$, and $\mathrm{Cu}$ is $0.01,0.01,0.003,0.05$ and $2 \mathrm{ppm}$, respectively. Environmental Protection Agency's Threshold Effect Level (EPA TEL) (MacDonald et al. 2000) for sediment $\mathrm{As}, \mathrm{Pb}, \mathrm{Cd}, \mathrm{Cr}$, and $\mathrm{Cu}$ is 5.9, 35, 0.596, 37.3 and $35.7 \mathrm{ppm}$, respectively. FAO of the United Nations guideline value (FAO 1983) for fish As, $\mathrm{Pb}, \mathrm{Cd}, \mathrm{Cr}$, and $\mathrm{Cu}$ is $0.1,0.40,0.10,1.0$ and $30 \mathrm{ppm}$, respectively. 
Following formula was used to calculate total concentration of each metal:

$$
\text { Total concentration }=\frac{\text { Concentration } \times \text { Volums } \times \text { Dilution fector }}{\text { Dry weight }}=\mathrm{ppm}
$$

here, Concentration $=$ AAS reading, volume $=$ Total volume of digested solution, dilution factor $=$ Final volume $/$ solute volume .

Statistical analysis: The data were statistically analyzed using the statistical packages, XLSTAT 2014 (Pearson Edition) by Addinsoft and NCSS 12.0.2 Statistical Software (2018) by NCSS, LLC. The mean and standard error were also calculated. Two samples two-tailed $t$ test were used to assess whether water and sediment samples varied significantly between wet and dry seasons, probabilities less than 0.05 ( $\mathrm{p}<0.05$ ) were considered statistically significant. Individual heavy metal concentrations of three samples (sample size $=3$ ) of each fish species were put in each column and one-way analysis of variation (ANOVA) was used to assess whether fish samples varied significantly among fish groups of different feeding habits, probabilities less than $0.05(\mathrm{p}<0.05)$ were considered statistically significant.

\section{RESULTS AND DISCUSSION}

Heavy metal concentrations in water: As concentration in river water ranges from BDL-0.0019 ppm during the wet season and $0.0016-0.0180$ during the dry season (Table 1) but there is no significant seasonal variation $(\mathrm{p}<0.05)$. Average As concentration in water was below WHO guideline value during both seasons thus, river water was not contaminated with As during both wet and seasons. $\mathrm{Pb}$ concentration in river water ranged from $0.3702-0.4163 \mathrm{ppm}$ during the wet season and 0.1305 - 0.1889 during the dry season (Table 1) and there is significant seasonal variation $(\mathrm{p}<0.05)$. Water $\mathrm{Pb}$ concentration was higher in the wet season than the dry season. Average $\mathrm{Pb}$ concentration in water was higher than WHO guideline value during both seasons thus, river water was contaminated with $\mathrm{Pb}$ during both seasons. $\mathrm{Cd}$ concentration in river water ranges from $0.0285-0.0294 \mathrm{ppm}$ during the wet season and $0.0297-0.0309$ during the dry season (Table 1) and there is significant seasonal variation ( $<<$ 0.05). Water $\mathrm{Cd}$ concentration was higher in the dry season than the wet season. Average $\mathrm{Cd}$ concentration in water was much higher than WHO guideline value during both seasons thus, river water was highly contaminated with Cd during both seasons. Cr concentration in river water ranges from 1.204 - 1.36 ppm during the wet season and BDL during the dry season (Table 1) and there is significant seasonal variation $(\mathrm{p}<0.05)$. Water $\mathrm{Cr}$ concentration was 
higher in the wet season than the dry season. Average Cr concentration in water was above WHO guideline value during the wet season but below WHO guideline value during the dry season thus, river water was contaminated with $\mathrm{Cr}$ only during thewet season. $\mathrm{Cu}$ concentration in river water ranges from 0.0315$0.0807 \mathrm{ppm}$ during the wet season and $0.0381-0.0543 \mathrm{ppm}$ during the dry season (Table 1) but there is no significant seasonal variation $(\mathrm{p}<0.05)$. Average $\mathrm{Cu}$ concentration in water was below WHO guideline value during both seasons thus, river water was not contaminated with $\mathrm{Cu}$ during both seasons. Heavy metal concentrations in the river water decreased in the sequence of $\mathrm{Cr}>\mathrm{Pb}>$ $\mathrm{Cu}>\mathrm{Cd}>\mathrm{As}$ and $\mathrm{Pb}>\mathrm{Cu}>\mathrm{Cd}>\mathrm{As}>\mathrm{Cr}$ during the wet and the dry seasons, respectively.

Table 1. Value of the heavy metal concentrations recorded from the water of different spots of the Dhaleshwari river during wet and dry seasons

\begin{tabular}{lcccccccccc}
\hline \multirow{2}{*}{ Spot } & \multicolumn{2}{c}{ As $(\mathrm{ppm})$} & \multicolumn{2}{c}{ Pb $(\mathrm{ppm})$} & \multicolumn{2}{c}{ Cd $(\mathrm{ppm})$} & \multicolumn{2}{c}{ Cr $(\mathrm{ppm})$} & \multicolumn{2}{c}{$\mathrm{Cu}(\mathrm{ppm})$} \\
\cline { 2 - 11 } & Wet & Dry & Wet & Dry & Wet & Dry & Wet & Dry & Wet & Dry \\
\hline Spot 1 & 0.0019 & 0.0180 & 0.3855 & 0.1520 & 0.0285 & 0.0300 & 1.34 & BDL & 0.0733 & 0.0430 \\
Spot 2 & 0.0007 & 0.0056 & 0.3702 & 0.1889 & 0.0291 & 0.0309 & 1.204 & $"$ & 0.0622 & 0.0543 \\
Spot 3 & 0.0014 & 0.0059 & 0.4163 & 0.1305 & 0.0288 & 0.0297 & 1.36 & $"$ & 0.0315 & 0.0430 \\
Spot 4 & BDL & 0.0016 & 0.3487 & 0.1705 & 0.0287 & 0.0305 & 1.33 & $"$ & 0.0573 & 0.0381 \\
Spot 5 & $"$ & 0.0026 & 0.3702 & 0.1827 & 0.0294 & 0.0303 & 1.27 & $"$ & 0.0807 & 0.0536 \\
Mean \pm & $0.0008 \pm$ & 0.0067 & 0.3782 & 0.1649 & $0.0289 \pm$ & $0.0302 \pm$ & 1.3008 & & $0.061 \pm$ & 0.0464 \\
SE & 0.0003 & \pm 0.002 & \pm 0.01 & \pm 0.01 & 0.0001 & 0.0002 & \pm 0.03 & & 0.008 & \pm 0.003 \\
WHO guideline & \multicolumn{2}{c}{0.01} & \multicolumn{2}{c}{0.01} & \multicolumn{2}{c}{0.003} & & 0.05 & 2 \\
\hline
\end{tabular}

*SE $=$ Standard error, WHO = World Health Organization.

Heavy metal concentrations in sediments: As concentration in river sediment ranged from 3.67-7.13 ppm during the wet season and 5.10-8.88 ppm during the dry season (Table 2) but there was no significant seasonal variation ( $\mathrm{p}<$ 0.05). Average As concentration in sediment was below EPA TEL during the wet season but was higher than EPA TEL during the dry season thus, river sediment was contaminated with As only during the dry season. Pb concentration in river sediment ranges from 21.58 - 64.96 ppm during the wet season and 19.27 $30.75 \mathrm{ppm}$ during the dry season (Table 2) but there was no significant seasonal variation $(\mathrm{p}<0.05)$. Average $\mathrm{Pb}$ concentration in sediment was above EPA TEL during the wet season but was below EPA TEL during the dry season thus, river sediment was contaminated with $\mathrm{Pb}$ only during the wet season. $\mathrm{Cd}$ concentration in river sediment ranges from $1.36-1.72 \mathrm{ppm}$ during the wet season and $1.39-1.48 \mathrm{ppm}$ during the dry season (Table 2) but there was no significant seasonal variation $(\mathrm{p}<0.05)$. The average $\mathrm{Cd}$ concentration in sediment was higher than EPA TEL during both seasons thus, river sediment was contaminated with $\mathrm{Cd}$ during both wet and dry seasons. $\mathrm{Cr}$ concentration in 
river sediment ranges from 1126.66 - $1199.46 \mathrm{ppm}$ during the wet season and 99.67 - $446.72 \mathrm{ppm}$ during the dry season (Table 2) and there was significant seasonal variation $(\mathrm{p}<0.05)$. Sediment $\mathrm{Cr}$ concentration was higher in the wet season than the dry season.

Table 2. Value of the heavy metal concentrations recorded from sediment of different spots of the Dhaleshwari river during wet and dry seasons

\begin{tabular}{|c|c|c|c|c|c|c|c|c|c|c|}
\hline \multirow{2}{*}{ Spot } & \multicolumn{2}{|c|}{ As (ppm) } & \multicolumn{2}{|c|}{$\mathrm{Pb}(\mathrm{ppm})$} & \multicolumn{2}{|c|}{$\mathrm{Cd}$ (ppm) } & \multicolumn{2}{|c|}{$\mathrm{Cr}(\mathrm{ppm})$} & \multicolumn{2}{|c|}{$\mathrm{Cu}(\mathrm{ppm})$} \\
\hline & Wet & Dry & Wet & Dry & Wet & Dry & Wet & Dry & Wet & Dry \\
\hline Spot 1 & 6.50 & 7.50 & 21.58 & 19.27 & 1.36 & 1.48 & 1199.46 & 250.189 & 108.07 & 216.44 \\
\hline Spot 2 & 4.97 & 5.10 & 52.86 & 29.57 & 1.42 & 1.41 & 1126.66 & 117.53 & 45.91 & 68.98 \\
\hline Spot 3 & 3.67 & 8.75 & 64.96 & 30.75 & 1.54 & 1.39 & 1161.87 & 367.03 & 58.05 & 442.78 \\
\hline Spot 4 & 7.13 & 8.88 & 28.36 & 28.62 & 1.39 & 1.44 & 1173.24 & 99.67 & 115.56 & 82.25 \\
\hline Spot 5 & 4.45 & 5.29 & 21.69 & 25.35 & 1.72 & 1.47 & 1159.10 & 446.72 & 115.57 & 74.07 \\
\hline $\begin{array}{c}\text { Mean } \pm S \\
\text { E }\end{array}$ & $\begin{array}{c}5.34 \pm \\
0.64\end{array}$ & $\begin{array}{l}7.11 \pm \\
0.82\end{array}$ & $\begin{array}{l}37.89 \\
\pm 8.88\end{array}$ & $\begin{array}{l}26.71 \\
\pm 2.07\end{array}$ & $\begin{array}{l}1.49 \pm \\
0.07\end{array}$ & $\begin{array}{l}1.44 \pm \\
0.02\end{array}$ & $\begin{array}{c}1164.07 \\
\pm 11.8\end{array}$ & $\begin{array}{c}256.23 \pm \\
67.95\end{array}$ & $\begin{array}{c}88.63 \pm \\
15.15\end{array}$ & $\begin{array}{c}176.904 \\
\pm 71.9\end{array}$ \\
\hline EPA TEL & \multicolumn{2}{|c|}{5.9} & \multicolumn{2}{|c|}{35} & \multicolumn{2}{|c|}{0.596} & \multicolumn{2}{|c|}{37.3} & \multicolumn{2}{|c|}{35.7} \\
\hline
\end{tabular}

*SE $=$ Standard error, EPA TEL = Environmental protection agency's threshold effect level.

The average $\mathrm{Cr}$ concentration in sediment was higher than EPA TEL during both seasons thus, river sediment was contaminated with $\mathrm{Cr}$ during both wet and dry seasons. $\mathrm{Cu}$ concentration in river sediment ranges from 45.91-115.57 ppm during the wet season and 68.98 - 442.78 ppm during the dry season (Table 2 ) but there was no significant seasonal variation $(0.05<\mathrm{p})$. Average $\mathrm{Cu}$ concentration in sediment was higher than EPA TEL during both seasons thus, we concluded that river sediment was contaminated with $\mathrm{Cu}$ during both wet and dry seasons. Heavy metal concentrations in the river sediment decreased in the sequence of $\mathrm{Cr}>\mathrm{Cu}>\mathrm{Pb}>\mathrm{As}>\mathrm{Cd}$ and $\mathrm{Cr}>\mathrm{Cu}>\mathrm{Pb}>\mathrm{As}>\mathrm{Cd}$ during the wet season and the dry season, respectively.

Heavy metal concentrations in fish samples: The average concentration of As, $\mathrm{Pb}, \mathrm{Cd}, \mathrm{Cr}$ and $\mathrm{Cu}$ in L. rohita was $0.09,21.80,2.06,7.87$ and $40.76 \mathrm{ppm}$, respectively. The order of toxicity of different heavy metals in different tissues of L. rohita samples was $\mathrm{As}<\mathrm{Cd}<\mathrm{Cr}<\mathrm{Pb}<\mathrm{Cu}$ (Table 3). The average concentration of $\mathrm{As}, \mathrm{Pb}, \mathrm{Cd}, \mathrm{Cr}$, and $\mathrm{Cu}$ in $W$. attu was $\mathrm{BDL}, 43.57 \mathrm{ppm}, 6.3$, 18.80 and $2.09 \mathrm{ppm}$, respectively. The order of toxicity of different heavy metals in different tissues of $W$. attu samples was $\mathrm{As}<\mathrm{Cu}<\mathrm{Cd}<\mathrm{Cr}<\mathrm{Pb}$ (Table 3). The average concentration of $\mathrm{As}, \mathrm{Pb}, \mathrm{Cd}, \mathrm{Cr}$, and $\mathrm{Cu}$ in $H$. fossilis was $\mathrm{BDL}, 64.49$, $6.38,4.51 \mathrm{ppm}$ and BDL, respectively. The order of toxicity of different heavy metals in different tissues of $H$. fossilis samples was $\mathrm{As} \leq \mathrm{Cu}<\mathrm{Cr}<\mathrm{Cd}<\mathrm{Pb}$ (Table 3). 
As and $\mathrm{Cu}$ concentrations varied significantly $(\mathrm{p}<0.05)$ among fishes of different feeding behavior. The order of concentrations of As and $\mathrm{Cu}$ among different fish groups was Omnivorous $<$ Herbivorous $<$ Carnivorous. There was no significant variation $(\mathrm{p}>0.05)$ of $\mathrm{Pb}, \mathrm{Cd}$ and $\mathrm{Cr}$ concentrations among fishes of different feeding behavior.

Table 3. Heavy metal bioaccumulation in different tissues of selected fish samples

\begin{tabular}{llclccc}
\hline Species & Tissue & As (ppm) & Pb (ppm) & Cd (ppm) & Cr (ppm) & Cu (ppm) \\
\hline Labeo rohita & Muscle & BDL & BDL & BDL & BDL & 26.60 \\
& Gill & 0.28 & 63.45 & 6.17 & 23.49 & 45.06 \\
& Gut & $\mathrm{BDL}$ & 1.97 & $\mathrm{BDL}$ & 0.12 & 50.63 \\
& Average & 0.09 & 21.80 & 2.06 & 7.87 & 40.76 \\
Wallago attu & Muscle & $\mathrm{BDL}$ & 3.28 & 1.00 & $\mathrm{BDL}$ & $\mathrm{BDL}$ \\
& Gill & $\mathrm{BDL}$ & 126.40 & 16.77 & 47.30 & 3.13 \\
& Gut & $\mathrm{BDL}$ & 1.02 & 1.13 & 9.11 & 3.13 \\
sfossilis & Average & $\mathrm{BDL}$ & 43.57 & 6.3 & 18.80 & 2.09 \\
& Muscle & $\mathrm{BDL}$ & 63.63 & 6.22 & 4.52 & $\mathrm{BDL}$ \\
& Gill & $\mathrm{BDL}$ & 65.87 & 6.54 & 4.52 & $\mathrm{BDL}$ \\
& Gut & $\mathrm{BDL}$ & 63.97 & 6.37 & 4.48 & $\mathrm{BDL}$ \\
& Average & $\mathrm{BDL}$ & 64.49 & 6.38 & 4.51 & BDL \\
\hline
\end{tabular}

$\mathrm{BDL}=$ Below detection level.

Concentration of As was below FAO guideline value while the concentrations of $\mathrm{Pb}, \mathrm{Cd}$ and $\mathrm{Cr}$ were higher than $\mathrm{FAO}$ guideline value in all selected fish species. $\mathrm{Cu}$ concentration was above FAO guideline value in one species $(H$. fossilis). At least three heavy metal concentrations were above FAO guideline values in all three fish species. Therefore, findings of this study suggested that the selected fish species were not safe for human consumption.

This study showed that heavy metal concentrations in water, sediment and selected fish samples of the Dhaleshwari river were above standard acceptable values thus, recorded as severely contaminated with heavy metals. Findings reflected the similar study conducted by Bhuyan and Islam (2017) that revealed heavy metals accumulated in sediment at a considerable amount and finally enter into the food chain. Throughout this study period, $\mathrm{Pb}$ and $\mathrm{Cd}$ concentrations of Dhaleshwari river water were higher than similar studies conducted by Arefin et al. (2016) in Turag river. This study recorded $\mathrm{Cr}, \mathrm{Cu}, \mathrm{Pb}$ and Cd concentrations of Dhaleshwari river water were slightly higher than the findings of Ahmed et al. (2012). Concentrations of $\mathrm{Cr}, \mathrm{Pb}, \mathrm{Cd}$ and in river sediment collected from Dhaleshwari river were higher than the findings of Mohiuddin et al. (2016) who conducted similar study in Buriganga river. This 
study reported that the concentrations of $\mathrm{Cr}, \mathrm{Cu}, \mathrm{Pb}$ and $\mathrm{Cd}$ in the river sediment were much higher than the findings of Ahmed et al. (2012).

According to Akan et al. (2012), fishes are the most important and vulnerable species that are susceptible to heavy metals pollution which supported the finding of this study. However, Ahsan et al. (2018) recorded the concentrations of $\mathrm{As}, \mathrm{Pb}, \mathrm{Cd}$ and $\mathrm{Cr}$ in fish samples of the Dhaleshwari River were below standard acceptable values and were not contaminated with heavy metals. But the present study showed that concentrations of $\mathrm{As}, \mathrm{Pb}, \mathrm{Cd}$ and $\mathrm{Cr}$ in fish samples were above standard acceptable values thus, contaminated with heavy metals. Bhuyan and Islam (2017) reported that industries adjacent to the rivers influence heavy metal pollution in the river as well as in the relevant food chain. So, the possible reason for the high value of heavy metals in the water, sediments and selected fish species in this study could be the tannery industries adjacent to the study area as well as to the sampling sites (Fig. 1). The discharge effluents from the industries contributed severely to the pollutions of the study area. Both Ahmed et al. (2012) and Ahsan et al. (2018) carried out their study on Dhaleshwari river that is similar to the present study, but their sampling sites were different from this study and the studies were performed at different period of the year which might be another significant purpose behind the varieties of the outcomes among present study and their investigations.

From the foregoing discussion it is revealed that the heavy metal concentrations in the water, sediment, and fish species were above the WHO, EPA, and FAO standard acceptable limits. Therefore, drinking of river water and consumption of fishes from the studied spots of the Dhaleshwari River did not comply with health safety issues and may cause serious health problems. To save the aquatic biota of the Dhaleshwari river from existing pollution, the Government should take adequate measures to make Central Effluent Treatment Plant (CETP) more efficient. More study is required to investigate the negative impacts of tannery effluents on aquatic biota of Dhaleshwari river. Regular monitoring of river water quality should be done in order to better understand current pollution status which will aid in decision making and implementation of new innovative technologies to mitigate existing pollution.

\section{LITERATURE CITED}

AHMED, A.T.A., MANDAL, S., CHOWDHURY, D.A., TAREQ, A.R.M. and RAHMAN, M.M. 2012. Bioaccumulation of some heavy metals in ayre fish (Sperata aor Hamilton, 1822), Sediment and Water of Dhaleshwari river in dry season. Bangladesh J. Zool. 40(1): 147-153.

AHSAN, M.A., SIDDIQUE, M.A.B., MUNNI, M.A., AKBOR, M.A., BITHI, U.H., MIA, M.Y. and SIDDIQUE, M.A.B. 2018. Analysis of major heavy metals in the available fish species of the Dhaleshwari river, Tangail, Bangladesh. Int. J. Fish. Aquat. Stud. 6(4): 349-354. 
AKAN, J.C., MOHMOUD, S., YIKALA, B.S. and OGUGBUAJA, V.O. 2012. Bioaccumulation of some heavy metals in fish samples from river Benue in Vinikilang, Adamawa State, Nigeria. Am. J. Anal. Chem. 03: 727-736.

ALAM, M.K. 2003. Cleanup of the Buriganga river: Integrating the Environment into Decision Making, PhD Thesis, Murdoch University, Australia.

AOAC (ASSOCIATION OF OFFICIAL AGRICULTURAL CHEMISTS) INTERNATIONAL. 2002. Lead, cadmium, copper, iron and zink in foods atomic absorption spectroscopy after dry ashing. AOAC Official Method 999.11.

AREFIN, M.T., RAHMAN, M.M., WAHID-U-ZZAMAN, M. and KIM, J.E. 2016. Heavy metal contamination in surface water used for irrigation: Functional assessment of the Turag river in Bangladesh. J. Appl. Biol. Chem. 59(1): 83-90.

AYANGBENRO, A.S. and BABALOLA, O.O. 2017. A new strategy for heavy metal polluted environments: A review of microbial biosorbents. Int. J. Environ. Res. Public Health 14(94): 1-16.

BHUYAN, M.S. and ISLAM, M.S. 2017. A critical review of heavy metal pollution and its effects in Bangladesh. Sci. J. Energy Eng. 5: 95.

EPA (ENVIRONMENTAL PROTECTION AGENCY). 1997. Recommended guidelines for sampling marine sediment, water column, and tissuein Puget Sound. U.S. Environmental Protection Agency, Region 10, 1200 Sixth Avenue, Seattle, Washington. pp. vi+52.

FAO (FOOD AND AGRICULTURE ORGANIZATION). 1983. Compilation of legal limits for hazardous substances in fish and fishery products. FAO Fisheries Circular No. 464. pp. 5-100.

IUCN (INTERNATIONAL UNION FOR CONSERVATION OF NATURE) Bangladesh. 2015. Red List of Bangladesh Volume 5: Freshwater Fishes. IUCN, International Union for Conservation of Nature, Bangladesh Country Office, Dhaka, Bangladesh. pp. xvi+360.

MACDONALD, D.D., INGERSOLL, C.G. and BERGER, T.A. 2000. Development and evaluation of consensus-based sediment quality guidelines for freshwater ecosystems. Arch. Env. Contam. Toxicol. 39: 20-31.

MACKLIN, M.G., BREWER, P.A., HUDSON-EDWARDS, K.A., BIRD, G., COULTHARD, T.J. and DENNIS, I.A. 2006. A geomorphological approach to the management of rivers contaminated by metal mining. Geomorphology 79: 423-447.

MAI, H. X., ZHANG, Y. W., SI, R., YAN, Z. G., SUN, L. D., YOU, L. P. and YAN, C. H. 2006. Highquality sodium rare-earth fluoride Nanocrystals: Controlled synthesis and optical properties. $J$. Am. Chem. Soc. 128(19): 6426-6436.

MANSOUR, S.A. and SIDKY, M.M. 2002. Ecotoxicological Studies: Heavy Metals Contaminating Water and Fish from Fayum Governorate, Egypt. Food Chem. 78(1):15-22.

MARTIN, C.W. 2000. Heavy metal trends in floodplain sediments and valley fill, River Lahn, Germany. Catena. 39: 53-68.

MOHIUDDIN, K., ALAM, M., AHMED, I. and CHOWDHURY, A. 2016. Heavy metal pollution load in sediment samples of the Buriganga river in Bangladesh. J. Bangladesh Agric. Univ. 13: 229-238.

REZA, R. and SINGH, G. 2010. Heavy metal contamination and its indexing approach for river water. Int. J. Environ. Sci. Technol. 7: 785-92.

SATTER, M.A. and ISLAM, M.S. 2005. Quality assessment of river water around Dhaka City. Bangladesh J. Environ. Sci. 10: 326-329.

WHO (WORLD HEALTH ORGANIZATION). 2006. Guidelines for drinking-water quality [https://www.who.int/water_sanitation_health/dwq/gdwq0506.pdf]: incorporating first addendum. Vol. 1, Recommendations. - 3rd ed. pp. xxiv+515. 